\title{
Enhancement of E-Commerce Websites with Semantic Web Technologies
}

\author{
Sabina-Cristiana Necula ${ }^{1, *}$, Vasile-Daniel Păvăloaia ${ }^{2}$ (i), Cătălin Strîmbei ${ }^{2}$ and \\ Octavian Dospinescu 2 (i) \\ 1 Department of Research, Faculty of Economics and Business Administration, \\ Alexandru Ioan Cuza University of Iasi, 700506 Iaşi, Romania \\ 2 Department of Accounting, Business Information Systems and Statistics, \\ Faculty of Economics and Business Administration, Alexandru Ioan Cuza University of Iasi, \\ 700506 Iaşi, Romania; danpav@uaic.ro (V.-D.P.); linus@uaic.ro (C.S.); doctav@uaic.ro (O.D.) \\ * Correspondence: sabina.necula@uaic.ro; Tel.: +40-0232-201413
}

Received: 30 April 2018; Accepted: 8 June 2018; Published: 11 June 2018

\begin{abstract}
This paper analyses the potential enhancement of e-commerce websites with Semantic web technologies from the consumers' informational perceived satisfaction point of view. Information quality is a central preoccupation in the field of business information systems' discipline and it relates to the semantic interoperability field of research. The purpose of our study is to investigate the relationship between the enhancement of product text descriptions with semantic annotations and the perceived consumers' satisfaction. We conducted and analyzed a survey questionnaire addressed to e-commerce consumers who bought online products. We found that consumers are interested in finding products with synonym names or that belong to different categories, not necessarily from the same category of products. In addition, consumers are interested about additional text descriptions on different product characteristics and on information about the importance of product characteristics. The main conclusion is that the perceived satisfaction of the online consumers is influenced by an enhanced user experience that relates to specific Semantic web technologies.
\end{abstract}

Keywords: e-business; e-commerce; Semantic web; linked data; schema.org; ontology

\section{Introduction}

The sustainability of the business is a global contemporary issue [1-3]. With the World Wide Web, enormous amounts of information in any subject can be accessed at any time. With e-commerce, goods could be bought through a click of a mouse and be delivered at the doorstep [4]. The environmental effects of Information and Communication Technologies (ICT) were identified as [5]: the impacts and opportunities created by the physical existence of ICT and the processes involved (energy consumption of PCs, hardware waste, etc.); the impacts and opportunities created by the ongoing use and application of ICT (e.g., online shopping, satellite navigation systems in cars); and the impacts and opportunities created by the aggregated effects of large numbers of people using ICT over the medium- to long-term. This study addresses the purpose to maximize the positive impacts on the society and the environment through the design of information technology in e-commerce business websites so that users benefit from the use of semantic technologies.

In his study, Ekins [6] points out three fundamental types of changes that are required for more sustainable development. Among them, "satisfying present wants with technologies of vastly improved environmental performance" justifies our endeavors to prove that sustainability in e-business is strongly related to the consumers' perception on product information quality. 
The new era of cloud computing and web services changed the technologies and architectures of eBusiness. Google and Amazon entirely redefined their web applications and platforms so that they benefit from the full use of these technologies. Jarvis [7] states that every e-business or web application became a link in an interconnected linked world. An important component of e-business is e-commerce with each e-commerce business having a website. A website's usability is a fundamental property of e-commerce. A key aspect of e-commerce website's usability is user experience. Jacobson [8] states that the first law of e-commerce is that if users cannot find the product, they cannot buy it either.

Much of the current literature on e-business and web services pays particular attention to the architecture [9-12]. This kind of architecture supposes an intelligent data integration through dynamic dereferencing of data sources, without any proprietary drivers, proprietary formats, or even static referencing in data integration.

Even if all the existent solutions are well intended, the reality shows that the online consumer's satisfaction is still low due to some reasons. There is a consensus among researchers that the main causes are in relation with: (1) information content, product, transaction, technological, institutional, consumer's behavior [13]; (2) the quality of the online vendor/seller, the Internet quality, infrastructure or contextual factors [14]; (3) the informational content of the web site [15]; and (4) the navigation on the web site [16].

Previous studies have reported [17-20] there is still need of empirical studies in order to clarify the determinants of e-services quality and to measure the influence of these determinants on online consumer's perceptions. The quality of information from the online environment is considered to be a main preoccupation both in theory and practice [17,21].

Concerning the information quality, the majority of the studies are centered on the web site design $[15,16,22]$. Very often, the authors study the influence of information quality on the e-commerce web site quality without studying the determinants of information quality. Cheung and Lee [21] considered the accuracy, the content, the format, and the timeliness of information to be important. Liu et al. [17] showed that the accuracy, the intelligibility, the completeness, and the relevance of information are important for consumer's satisfaction. However, a major problem with these kinds of studies is not analyzing the information quality from the semantics perspective.

Central to the entire discipline of information quality is the concept of semantic interoperability. In recent years, there has been an increasing amount of literature on the semantic interoperability and its important role in the business information systems' field of research.

Moreover, Singh et al. [23] define semantic e-business as an approach to managing knowledge for the coordination of e-business processes through the systematic application of semantic web technologies. Semantic web technologies are by far the most often used for data integration and for improving the search [24]. The use of ontologies for knowledge sharing, heterogeneous database integration and semantic interoperability has been long realized [25-27].

In recent years, there has been an increasing interest in linked data. Linked data provides the capacity for establishing association links among concepts in different datasets, producing high-quality interlinked versions of semantically linked web datasets. Such interlinked datasets constitute valuable input for the initiation of a data mining and analysis process. Moreover, interlinked versions of datasets may be maintained or regularly updated, providing easy access to latest versions of the available datasets. Linked data also provides mechanisms for assessing the quality of the available data, since there is a need to handle data with different quality characteristics regarding their accuracy, consistency, timeliness, completeness, relevance, interpretability and trustworthiness.

Abramowicz et al. [28] states that linked data is beneficial where heterogeneous data needs to be exchanged between a variety of distributed systems and stakeholders. The authors note that there remain a significant number of domains where applying the linked data principles would be beneficial, but the concept is still largely unknown. These include finance, manufacturing and production, logistics and supply chain management, and enterprise data integration. 
Some elements of difficulty in the problem of semantic interoperability in e-commerce are: (1) the meaning of data. Due to heterogeneous sources of origin, different formats of data representation and a lack of connections between data, the meaning of data remains "hidden"; (2) the discovery of new meanings from existing data. Complications arise when the field is both structured and unstructured, and some of the context comes from unsafe sources.

There are limits to the current approaches: (1) Studies in the field of the semantic web are focused on discovering links between data, the development of ontologies, automatic annotation and data visualization, with few results in the area of business data. The study realized by Search Engine Watch in 2017 [29] reported that close to a quarter (24\%) of respondents still cited "Understanding Schema markup vocabulary" as one of their biggest obstacles to carrying out Schema markup. It could be argued that the following two challenges have to be faced towards the achievement of advanced analysis and evidence-based decision making that optimize results for small scale businesses and organizations: (1) the design of advanced but user-friendly analytics tools that can be easily integrated within the daily business processes of organizations and enterprises, and (2) the adoption of techniques that allow the production and consumption of combined datasets that were previously closed in disparate sources and can now be appropriately interlinked [30].

However, much uncertainty still exists about the relationship between the information quality on semantics' bases and consumers' perceived satisfaction.

Semantic web means for the users, in terms of sustainability, links between concepts, not necessarily between web pages. As opposite to the traditional web, where understanding requires natural language processing and background knowledge, with the semantic web, understanding requires following links and reasoning over logical formalisms.

The major objective of this study was to investigate the enhancement of product text descriptions with semantic annotations in relation with the perceived consumers' satisfaction and it was addressed through the four research hypotheses presented in the Materials and Methods section. This research seeks to address the question: is there any relationship between the perceived consumers' satisfaction and semantic annotations on the information about a product in e-commerce? The findings should make an important contribution to the field of semantic web applications in e-commerce. This paper has been divided into three parts. The first part begins by laying out the materials and methods, and looks at how we defined the main possible enhancements of products' text description on semantic web bases. The second part is dedicated to the results. The third part presents discussions of those results.

\section{Materials and Methods}

The information systems (IS) success model (alternatively, IS success model, or the Delone and McLean IS success model [31]) is an information systems theory which seeks to provide a comprehensive understanding of IS success. A representation of the IS success model according to Delone and McLean is presented in Figure 1.

Traditionally, IS success has been assessed by measuring the perceived user's satisfaction. Therefore, our study established the perceived consumers' satisfaction of e-commerce websites as the endogenous variable.

To measure information quality on semantic web bases, we identified the main enhancements that semantic web technologies can bring to e-commerce websites by studying the current field of research.

The semantic web provides a common framework that allows data to be shared and reused across application, enterprise, and community boundaries [30]. The semantic web is, therefore, regarded as an integrator across different content, information applications and systems. 


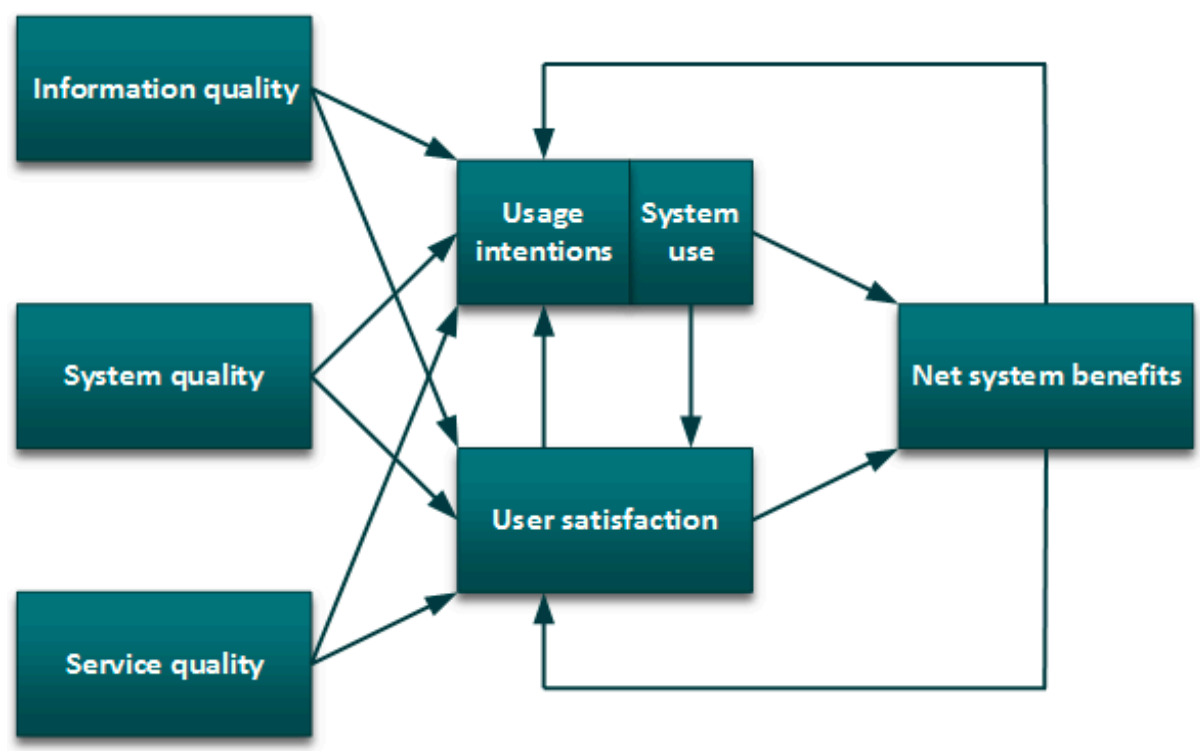

Figure 1. The representation of the IS success model [31].

The semantic web established languages specifically designed for data [32]: Resource Description Framework (RDF), Web Ontology Language (OWL), and Extensible Markup Language (XML). HTML describes documents and the links between them. RDF, OWL, and XML, by contrast, can describe arbitrary things, such as people, meetings, or airplane parts. Business applications include improving information retrieval, thereby reducing information overload and increasing the refinement and precision of the data retrieved.

The machine-readable descriptions enable content managers to add meaning to the content, to describe the structure of the knowledge about that content. In this way, a machine can process knowledge itself, instead of text, using processes similar to human deductive reasoning and inference, thereby obtaining results that are more meaningful and helping computers to perform automated information gathering and research [33].

Schema.org is one of the main drivers for the adoption of semantic web principles by a broad number of organizations and individuals for real business needs. GoodRelations is a well-established conceptual model for representing e-commerce information, one of the few widely used OWL DL ontologies, and since 2012 it has become the official e-commerce model of Schema.org [34]. GoodRelations improve search engine optimization for Google, Yahoo, Bing, and Yandex with schema.org, product information management, and e-commerce data quality management.

The main research question of our study is whether the online consumers' satisfaction is associated with semantic enhancements of the products' web site description in the online environment.

We identified the methods used to research information quality in relation with consumers' satisfaction, based on the studies presented in the introduction section of this paper. Table 1 displays a comparative analysis of related approaches in other papers that refer to the methods, the dependent and the independent variables.

In addition to the variables used in the related approaches (Table 1) our study is extending the list of antecedents of information quality by including the possible enhancements brought by semantic web technologies.

We propose the research model shown in Figure 2, by considering the semantic enhancements of the products' web site description. 
Table 1. Related work and research methods on studying information quality importance for e-commerce.

\begin{tabular}{|c|c|c|c|}
\hline Study & $\begin{array}{c}\text { Antecedents of Information } \\
\text { Quality }\end{array}$ & Dependent Variable & $\begin{array}{c}\text { Sample and } \\
\text { Research Method }\end{array}$ \\
\hline Evanschitzky et al. [35] & $\begin{array}{l}\text { Product information } \\
\text { Quality of information } \\
\text { Quantity of information }\end{array}$ & $\begin{array}{l}\text { Internet shopping experience } \\
\text { (very dissatisfied to } \\
\text { very satisfied) }\end{array}$ & $\begin{array}{l}n=298 \\
\text { Survey }\end{array}$ \\
\hline Szymanski and Hise [36] & $\begin{array}{l}\text { Product information } \\
\text { Quality of information } \\
\text { Quantity of information }\end{array}$ & $\begin{array}{l}\text { Consumer e-satisfaction: } \\
\text { (1-much worse than } \\
\text { traditional stores and } \\
\text { 7—much better than } \\
\text { traditional stores) }\end{array}$ & $\begin{array}{c}n=1007 \\
\text { Survey }\end{array}$ \\
\hline Liu et al. [17] & $\begin{array}{l}\text { Information quality } \\
\text { Understandability } \\
\text { Accuracy } \\
\text { Completeness } \\
\text { Relevancy }\end{array}$ & Online shopper satisfaction & $\begin{array}{c}n=1001 \\
\text { Survey }\end{array}$ \\
\hline Kim and Lim [37] & $\begin{array}{l}\text { Width of information } \\
\text { Update of information } \\
\text { Depth of information }\end{array}$ & $\begin{array}{l}\text { Correlated with } \\
\text { entertainment }\end{array}$ & $\begin{array}{l}n=254 \\
\text { Survey }\end{array}$ \\
\hline
\end{tabular}

H1: The possibility to get product search results oriented towards synonyms and word families is associated with

$\mathrm{H} 2$ : The possibility to search for products within categories and subcategories of characteristics and get back search results that contain products from different categories is associated with

H3: The possibility to have access to additional information organized dictionary of terms is associated with

H4: The possibility to analyze product characteristics depending on their importance for the consumer (ratings and reviews) is associated with

Figure 2. The research model. Source: own projection.

We derived these requests studying the literature. The literature is presented in Table 2. 
Table 2. Enhancements of e-commerce sites. Source: Own projection.

\begin{tabular}{|c|c|c|}
\hline Enhancement & Ideas/Techniques & Details \\
\hline $\begin{array}{l}\text { Synonym names } \\
\text { Singhal [38] }\end{array}$ & $\begin{array}{l}\text { Term Weighting, Query } \\
\text { Modification, Cluster } \\
\text { hypothesis, Natural } \\
\text { Language Processing }\end{array}$ & $\begin{array}{l}\text { "... adding synonyms of query words to the query } \\
\text { should improve search effectiveness. Early research in } \\
\text { IR relied on a thesaurus to find synonyms. However, } \\
\text { it is quite expensive to obtain a good general purpose } \\
\text { thesaurus. Researchers developed techniques to } \\
\text { automatically generate thesauri for use in } \\
\text { query modification. } \\
\text { Most of the automatic methods are based on analyzing } \\
\text { word co-occurrence in the documents (which often } \\
\text { produces a list of strongly related words)" }\end{array}$ \\
\hline $\begin{array}{l}\text { Categories and subcategories } \\
\text { of characteristics } \\
\text { Stolz and Hepp [39] }\end{array}$ & $\begin{array}{l}\text { An adaptive, instance driven } \\
\text { faceted search interface, } \\
\text { improving the depth of } \\
\text { product search and } \\
\text { comparison }\end{array}$ & $\begin{array}{l}\text { "... Support learning about the option space ... Thus, } \\
\text { users need a way to relax or refine their constraints } \\
\text { and preferences based on how those modify the size of } \\
\text { the option space ... a user interface could ask the user } \\
\text { for approval of a possible match between two product } \\
\text { features. In an RDF environment, corresponding } \\
\text { axioms can be easily added to the existing data as } \\
\text { named RDF graphs-potentially managed on a } \\
\text { per-user basis" }\end{array}$ \\
\hline $\begin{array}{l}\text { Dictionary of } \\
\text { terms/knowledge graphs } \\
\text { Paulheim [40], } \\
\text { Garcia-Crespo [41], } \\
\text { Guha et al. [42] }\end{array}$ & $\begin{array}{l}\text { Knowledge graph } \\
\text { refinement } \\
\text { knowledge-centred but } \\
\text { oriented to both knowledge } \\
\text { management and process } \\
\text { execution—-proof of concept } \\
\text { is centered in } \\
\text { sales-supporting }\end{array}$ & $\begin{array}{l}\text { "... with the advent of Linked Open Data sources like } \\
\text { DBpedia, and by Google's announcement of the } \\
\text { Google Knowledge Graph in 2012, representations of } \\
\text { general world knowledge as graphs have drawn a lot } \\
\text { of attention again" } \\
\text { "... addressing vastly simpler scenarios from Web } \\
\text { search has turned out to be the best practical route } \\
\text { toward structured data for artificial } \\
\text { personal assistants." }\end{array}$ \\
\hline $\begin{array}{l}\text { Analyze product } \\
\text { characteristics depending on } \\
\text { their importance } \\
\text { Krutil et al. [43] } \\
\text { Meymandpour and Davis [44] } \\
\text { Huang and Benyoucef [45], } \\
\text { Mihleisen and Bizer [46], } \\
\text { Bizer et al. [47] }\end{array}$ & $\begin{array}{l}\text { The use of formal source } \\
\text { code structure for classifying } \\
\text { a large collection of the } \\
\text { web content } \\
\text { Feature-based Metrics, } \\
\text { Information Content-Based } \\
\text { Similarities, } \\
\text { Edge-Counting Metrics }\end{array}$ & $\begin{array}{l}\text { "... using information derived from tags can boost } \\
\text { the classifiers performance" } \\
\text { "... there are three principle types of recommendation } \\
\text { engines: (1) Collaborative Filtering (CF)—the } \\
\text { collection of user ratings and browsing experiences } \\
\text { without any awareness about items that are being } \\
\text { suggested, Content-Based } \\
\text { Recommendation-well-defined descriptions of items, } \\
\text { and Knowledge-Based Recommendation-match user } \\
\text { preferences with item properties (features) ... hybrid } \\
\text { approaches attempt to integrate features of various } \\
\text { methods, in order to maximize the efficiency and } \\
\text { performance of the recommenders." }\end{array}$ \\
\hline $\begin{array}{l}\text { Ratings and reviews } \\
\text { Anastasiei and } \\
\text { Dospinescu [48] } \\
\text { Heath and Motta [49] }\end{array}$ & $\begin{array}{l}\text { Communication flow } \\
\text { SPARQL reasoning, } \\
\text { RDF data }\end{array}$ & $\begin{array}{l}\text { "... convert the satisfied customers into influencers } \\
\text { who will spread the word about the product" } \\
\text { "... This will form the basis for personalizing search } \\
\text { results, and providing recommendations, based on } \\
\text { which members of their social } \\
\text { network a user is most likely to trust for } \\
\text { recommendations in a given scenario" } \\
\text { "... Conventional reviewing and rating services on } \\
\text { the web have a number of limitations. They typically } \\
\text { represent closed worlds, by limiting the focus of } \\
\text { reviews to items from a specific domain, sold by a } \\
\text { particular company, or catalogued in the database of a } \\
\text { reviewing and rating web site..." }\end{array}$ \\
\hline
\end{tabular}

In order to address the four hypotheses, we asked the respondents different questions that are presented in Table 3. The enlisted questions forms the variables used in our study in order to validate the hypothesis. As such, we have used the test of independence to study the association between the endogenous variable and the exogenous variables (one-by-one). 
Table 3. The questions addressed to respondents.

\begin{tabular}{ll}
\hline Question & Hypothesis \\
\hline Are you satisfied with purchasing products online (Q1) & The endogenous variable \\
\hline $\begin{array}{l}\text { The degree in which the consumer prefers that the search results be oriented } \\
\text { towards synonyms and word families (Q5_1) }\end{array}$ & $\mathrm{H} 1$ \\
\hline $\begin{array}{l}\text { The degree in which the consumer prefers that the text descriptions } \\
\text { categorized, grouped by category (Q5_2) }\end{array}$ & $\mathrm{H} 2$ \\
\hline $\begin{array}{l}\text { The degree in which the consumer would like to have some explanations for } \\
\text { the product descriptions (Q5_3) }\end{array}$ & $\mathrm{H} 3$ \\
$\begin{array}{l}\text { The degree in which the consumer would like that these descriptions be } \\
\text { classified by importance (Q5_4) }\end{array}$ & $\mathrm{H} 4$ \\
\hline The degree in which the consumer is interested on ratings (Q6) & $\mathrm{H} 4$ \\
\hline The degree in which the consumer is interested on reviews (Q7) & $\mathrm{H} 4$ \\
\hline
\end{tabular}

Respondents were asked to respond on a five-point Likert-type scale to the questionnaire items, first for the overall satisfaction with online shopping, followed by the measures for the exogenous variables. Respondents were also asked about their frequency of using online shopping.

The statistical methods applied to this study in order to validate the formulated research hypothesis are specific to the variables used in the questionnaire. The association analysis (cross tabulation and chi-square test of independence/association) was applied to verify whether there were associations between the variables studied (Table 3) and testing the differences between the variables studied (the student test for the two-dimensional difference test and the chi-square test of concordance).

The research was conducted based on questionnaire that was distributed to 900 potential respondents. The criterion for creating the sample was to include young people from $\mathrm{Z}$ generation (also known as iGen) actually enrolled in different undergraduate programs at Faculty of Economics and Business Administration-FEBA (but all enrolled in the first year of study) during two academic years (spring of 2016-2017 and autumn of 2017-2018). Generation Z is well informed on design, features, media, and the Internet. These persons are interested in esthetic qualities of ads, augmented reality, and virtual reality. Though those who answered affirmatively at question Q1 (see Table 3) are the targeted audience, we also consider relevant the opinion of those respondents who do not act as online consumers. Their opinion is relevant as they are part of Generation $\mathrm{Z}$ and they are not purchasing online for reasons subjective to time changes, such as not yet having a smartphone and/or a credit/debit card, having fears for online shopping, etc. Additionally, some of them have previously been online consumers but because of the lack of well-structured descriptions of the online products may have left this category. The criteria for selecting the subjects were based on studying the informational content presented in e-commerce sites from the semantics' point of view. To measure each enhancement from Table 2, a question, asking to evaluate the degree in which the user appreciates the respective enhancement, was used. The size of the population is 900 and it obtained a total of 806 valid responses. The respondents have the following profile: the average age is 22 years, the majority $(75.8 \%)$ are women, they own a smartphone connected to the Internet and/or at least another device that allows them to browse online for products and possess a mean of online payment. Given the sample size, compared to the population size, and also by taking into account the fact that all students in the population (at this age) are comparable at national, and even European levels, we consider the sample as being representative. Data management and analysis were performed using SPSS 16.0 (2010) (IBM Corp., Armonk, NY, USA).

\section{Results}

We restate that the main research question of our study is whether the online consumers' satisfaction is associated with semantic enhancements of the products' web site description in the online 
environment. Consequently, in the following paragraphs we address the hypotheses as presented in Figure 2.

Hypothesis 1 (H1). When buying online, consumers are interested that the products are described using synonyms and term/word families, respectively, terms that belong to an ontology.

Table 4 lists the results obtained for the analysis of the test for independence between the online acquisition option for the consumers and their desire to orientate search results by synonyms and word families. Thus, we note that the participants in the study have very different opinions on this subject. Furthermore, respondents who purchase online products and classify the display of synonymous results and word families as being important (answered by agreement or partial agreement), are majorities, respectively $39.7 \%$ of all participants in the study. Of the remaining respondents $(60.3 \%)$ who purchase online, $22.7 \%$ have a neutral opinion on this subject and $37.6 \%$ disagree with the idea that the results should be semantic web-oriented. Therefore, based on the chi-square test we can validate H1 and assert that with a less than $5 \%$ assumption that respondents purchasing online products agree that the description and display of search results oriented by synonyms and word families is an important feature of products included on websites that conduct e-business.

Table 4. Cross-tabulation of respondents' options regarding the online acquisition and their desire that the search results to be semantic web oriented (by synonyms and word families). Source: own projection.

\begin{tabular}{|c|c|c|c|c|c|c|c|c|}
\hline & & & \multicolumn{5}{|c|}{$\begin{array}{c}\text { When You Visit a Website That Sells Online Products, Which Aspect } \\
\text { Related to the Product, Do You Consider Important (Q5)? [I Would Prefer } \\
\text { the Search Results to Be Oriented towards Synonyms and Word } \\
\text { Families] (Q5_5) }\end{array}$} & \multirow[t]{2}{*}{ Total } \\
\hline & & & Disagreement & $\begin{array}{c}\text { Partial } \\
\text { Disagreement }\end{array}$ & Neutral & $\begin{array}{c}\text { Partial } \\
\text { Agreement }\end{array}$ & Agreement & \\
\hline $\begin{array}{l}\text { Are you } \\
\text { purchasing } \\
\text { products } \\
\text { online (Q1)? }\end{array}$ & YES & $\begin{array}{c}\text { Count } \\
\% \text { within Q1 }\end{array}$ & $\begin{array}{c}89 \\
13.7 \%\end{array}$ & $\begin{array}{c}156 \\
23.9 \%\end{array}$ & $\begin{array}{c}148 \\
22.7 \%\end{array}$ & $\begin{array}{c}100 \\
15.3 \%\end{array}$ & $\begin{array}{c}159 \\
24.4 \%\end{array}$ & $\begin{array}{c}652 \\
100 \%\end{array}$ \\
\hline \multicolumn{2}{|c|}{ Total } & $\begin{array}{c}\text { Count } \\
\% \text { within Q1 }\end{array}$ & $\begin{array}{c}125 \\
15.5 \%\end{array}$ & $\begin{array}{c}187 \\
23.2 \%\end{array}$ & $\begin{array}{c}175 \\
21.7 \%\end{array}$ & $\begin{array}{c}136 \\
16.9 \%\end{array}$ & $\begin{array}{c}183 \\
22.7 \%\end{array}$ & $\begin{array}{c}806 \\
100 \%\end{array}$ \\
\hline \multicolumn{2}{|c|}{ Chi-Sqaure Tests } & $\begin{array}{c}p \text {-Value } \\
\text { Asymp. Sig. } \\
(2 \text {-sided })\end{array}$ & \multicolumn{6}{|c|}{0.014} \\
\hline
\end{tabular}

Hypothesis 2 (H2). When buying online, consumers are interested that the products' text descriptions of purchased products be classified and grouped by category.

The distribution of responses (included in Table 5) to the question that analyzes the respondents' opinion about the relevance of text descriptions for online purchased products to be classified and display the search results by categories and subcategories, outlines a clear trend of agreement in proportion of $48.5 \%$ (responded by agreement or partial agreement) and disagreement of $21.5 \%$, while $30.1 \%$ have a neutral opinion. The same trend occurs for respondents who do not purchase products online. Thus, their majority of $46.1 \%$ agree that displaying the search results classified by categories and subcategories is important, $31.8 \%$ disagreed and $22.1 \%$ had a neutral opinion. Therefore, based on the results of the test for association, we can state that there is a high association between variables analyzed. Moreover, with an assumed risk less than $5 \%$, we can affirm that online consumers agree that the search results for the purchased products should display the text descriptions classified by categories and subcategories and, thus, $\mathrm{H} 2$ is validated. 
Table 5. Cross-tabulation of respondents' options regarding the online acquisition and their desire that the products should have classified text descriptions, grouped by categories. Source: own projection.

\begin{tabular}{|c|c|c|c|c|c|c|c|c|}
\hline & & & \multicolumn{5}{|c|}{$\begin{array}{c}\text { When You Visit a Website That Sells Online Products, Which Aspect } \\
\text { Related to the Product, Do You Consider Important (Q5)? [I Like Text } \\
\text { Descriptions to Be Categorized, Grouped by Category. I Dislike When I } \\
\text { View the Product Description as Plain Text] (Q5_2) }\end{array}$} & \multirow[t]{2}{*}{ Total } \\
\hline & & & Disagreement & $\begin{array}{c}\text { Partial } \\
\text { Disagreement }\end{array}$ & Neutral & $\begin{array}{c}\text { Partial } \\
\text { Agreement }\end{array}$ & Agreement & \\
\hline \multirow{2}{*}{$\begin{array}{l}\text { Are you } \\
\text { purchasing } \\
\text { products } \\
\text { online (Q1)? }\end{array}$} & YES & $\begin{array}{c}\text { Count } \\
\% \text { within Q1 }\end{array}$ & $\begin{array}{c}45 \\
6.9 \%\end{array}$ & $\begin{array}{c}95 \\
14.6 \%\end{array}$ & $\begin{array}{c}196 \\
30.1 \%\end{array}$ & $\begin{array}{c}193 \\
29.6 \%\end{array}$ & $\begin{array}{c}123 \\
18.9 \%\end{array}$ & $\begin{array}{c}652 \\
100 \%\end{array}$ \\
\hline & $\mathrm{NO}$ & $\begin{array}{c}\text { Count } \\
\% \text { within Q1 }\end{array}$ & $\begin{array}{c}23 \\
14.9 \% \\
\end{array}$ & $\begin{array}{c}26 \\
16.9 \% \\
\end{array}$ & $\begin{array}{c}34 \\
22.1 \% \\
\end{array}$ & $\begin{array}{c}27 \\
17.5 \% \\
\end{array}$ & $\begin{array}{c}44 \\
28.6 \% \\
\end{array}$ & $\begin{array}{c}154 \\
100 \% \\
\end{array}$ \\
\hline \multicolumn{2}{|c|}{ Total } & $\begin{array}{c}\text { Count } \\
\% \text { within Q1 }\end{array}$ & $\begin{array}{c}68 \\
8.4 \% \\
\end{array}$ & $\begin{array}{c}121 \\
15.0 \%\end{array}$ & $\begin{array}{c}230 \\
28.5 \%\end{array}$ & $\begin{array}{c}220 \\
27.3 \%\end{array}$ & $\begin{array}{c}167 \\
20.7 \%\end{array}$ & $\begin{array}{c}806 \\
100 \%\end{array}$ \\
\hline \multicolumn{2}{|c|}{ Chi-Square Tests } & $\begin{array}{l}p \text {-Value } \\
\text { Asymp. Sig. } \\
\text { (2-sided) }\end{array}$ & \multicolumn{6}{|c|}{25.067} \\
\hline
\end{tabular}

Hypothesis 3 (H3). When buying online, consumers are interested that the products' text descriptions of purchased products be accompanied by explanations that refer to online dictionaries of terms of where the consumer may be further informed.

For the third analysis performed in the present study, a clear differentiation of the respondents on the three values of the response scale towards asserting the agreement, neutrality, and disagreement on including explanations in the description of products being sold online. Thus, the great majority of respondents $(64.4 \%)$ agree $(31.9 \%)$, or partially agree $(32.5 \%)$, with the above-mentioned aspect, while only $3.7 \%$ disagree or disagree partially $(6.1 \%)$, and $25.8 \%$ adopt a neutral opinion. Moreover, the same majority trend on this topic is also evident for respondents who do not purchase online products. The result of the chi-square test display that the two variables analyzed are dependent. A proportion of $53.9 \%$ of respondents that do not purchase online agreed that providing explanations in the description of the product characteristics is desired, while $27.9 \%$ have a disagreement and $18.2 \%$ have a neutral opinion. The results in Table 6 validate $\mathrm{H} 3$ and, with a risk less than $5 \%$ we can assert there is a majority interest among the online buyers for the availability of explanations among the description of product features on an online site.

Table 6. Cross-tabulation of respondents' options regarding the online acquisition and their desire that the product characteristics to have explanations attached. Source: own projection.

\begin{tabular}{|c|c|c|c|c|c|c|c|c|}
\hline & & & \multicolumn{5}{|c|}{$\begin{array}{l}\text { When You Visit a Website That Sells Online Products, Which Aspect } \\
\text { Related to the Product, Do You Consider Important (Q5)? [I Would Like } \\
\text { to Have Some Explanations for the Product Descriptions] (Q5_3) }\end{array}$} & \multirow[t]{2}{*}{ Total } \\
\hline & & & Disagreement & $\begin{array}{c}\text { Partial } \\
\text { Disagreement }\end{array}$ & Neutral & $\begin{array}{c}\text { Partial } \\
\text { Agreement }\end{array}$ & Agreement & \\
\hline \multirow{3}{*}{$\begin{array}{c}\text { Are you } \\
\text { purchasing } \\
\text { products } \\
\text { online (Q1)? }\end{array}$} & \multirow{2}{*}{ YES } & Count & 24 & 40 & 168 & 212 & 208 & 652 \\
\hline & & \% within Q1 & $3.7 \%$ & $6.1 \%$ & $25.8 \%$ & $32.5 \%$ & $31.9 \%$ & $100 \%$ \\
\hline & NO & \% within Q1 & $9.7 \%$ & $18.2 \%$ & $18.2 \%$ & $22.1 \%$ & $31.8 \%$ & $100 \%$ \\
\hline \multirow{2}{*}{\multicolumn{2}{|c|}{ Total }} & Count & 39 & 68 & 196 & 246 & 257 & 806 \\
\hline & & \% within Q1 & $4.8 \%$ & $8.4 \%$ & $24.3 \%$ & $30.5 \%$ & $31.9 \%$ & $100 \%$ \\
\hline \multirow{2}{*}{\multicolumn{2}{|c|}{ Chi-Square Tests }} & $p$-Value & \multicolumn{6}{|c|}{38.276} \\
\hline & & $\begin{array}{l}\text { Asymp. Sig. } \\
\text { (2-sided) }\end{array}$ & \multicolumn{6}{|c|}{0.000} \\
\hline
\end{tabular}


Hypothesis 4 (H4). When buying online, consumers are interested in being able to view characteristics of purchased products classified and ordered according to their importance (elements offered through rating and review).

In the attempt to assess the extent to which the classification for the descriptions based on the importance, for products marketed online on an e-business site, we present in Table 7 the results of the test for independence. It is observed there is a majority of online consumer consensus (56.7\%) toward agreement to classify by importance the product descriptions, while only $15.9 \%$ disagree with this and $27.6 \%$ have a neutral opinion. As such we highlight that the majority (as well) of respondents who do not purchase online products $(53.9 \%)$ agree that the description of the products should be classified by importance, $26.6 \%$ disagree, while $19.5 \%$ have a neutral position.

Table 7. Cross-tabulation of respondents' options regarding the online acquisition and their desire that the products should have a description classified based on importance. Source: own projection.

\begin{tabular}{|c|c|c|c|c|c|c|c|c|}
\hline & & & \multicolumn{5}{|c|}{$\begin{array}{c}\text { When You Visit a Website That Sells Online Products, Which Aspect } \\
\text { Related to the Product, Do You Consider Important (Q5)? [I Would Like } \\
\text { That These Descriptions Be Classified as Importance] (Q5_4) }\end{array}$} & \multirow{2}{*}{ Total } \\
\hline & & & Disagreement & $\begin{array}{c}\text { Partial } \\
\text { disagreement }\end{array}$ & Neutral & $\begin{array}{c}\text { Partial } \\
\text { agreement }\end{array}$ & Agreement & \\
\hline \multirow{4}{*}{$\begin{array}{c}\text { Are you } \\
\text { purchasing } \\
\text { products } \\
\text { online (Q1)? }\end{array}$} & \multirow[b]{2}{*}{ YES } & Count & 32 & 72 & 180 & 216 & 152 & 652 \\
\hline & & \% within Q1 & $4.9 \%$ & $11 \%$ & $27.6 \%$ & $33.1 \%$ & $23.3 \%$ & $100 \%$ \\
\hline & \multirow{2}{*}{$\mathrm{NO}$} & Count & 9 & 32 & 30 & 54 & 29 & 154 \\
\hline & & \% within Q1 & $5.8 \%$ & $20.8 \%$ & $19.5 \%$ & $35.1 \%$ & $18.8 \%$ & $100 \%$ \\
\hline \multirow{2}{*}{\multicolumn{2}{|c|}{ Total }} & Count & 41 & 104 & 210 & 270 & 181 & 806 \\
\hline & & \% within Q1 & $5.1 \%$ & $12.9 \%$ & $26.1 \%$ & $33.5 \%$ & $22.5 \%$ & $100 \%$ \\
\hline \multirow{2}{*}{\multicolumn{2}{|c|}{ Chi-Square Tests }} & $p$-Value & \multicolumn{6}{|c|}{13.778} \\
\hline & & $\begin{array}{l}\text { Asymp. Sig. } \\
\text { (2-sided) }\end{array}$ & \multicolumn{6}{|c|}{0.008} \\
\hline
\end{tabular}

The level of significance of the chi-square test below the assumed 5\% risk allows us to assert that online consumers are strongly influenced by the importance-based classification of the descriptions accompanying the products marketed on e-business platforms and, thus, validating $\mathrm{H} 4$ as well.

Moreover, in order to emphasize the importance of rating and review in strict correlation with the desire of the online consumer to receive descriptions classified by importance, we conducted the analysis presented in Table 8 where we grouped answers to questions that assess the importance of Ratings (Q6) and Reviews (Q7) and we have calculated their average mean and then we linked the values obtained with the scale of answers to the question (Q5_4) that tests the relevance of the description classified by importance.

Table 8. The association between the average mean of ratings and reviews and the classification of descriptions based on importance. Source: own projection.

\begin{tabular}{ccc}
\hline When You Visit a Website That Sells Online Products Which Aspect & Ratings (Q6) and Reviews (Q7) \\
\cline { 2 - 2 } Related to the Product Do You Consider Important (Q5) & Mean \\
\hline & Disagreement & 2.74 \\
I would like that these & Partial disagreement & 3.13 \\
descriptions be classified by & Neutral & 3.15 \\
importance (Q5_4) & Partial agreement & 3.37 \\
& Agreement & 3.48 \\
\hline
\end{tabular}

It can be noticed that the highest average mean value of answers to the questions that test the importance of ratings and reviews, on a scale of values from 1 to 5 , are related to the agreement (3.48) and partial agreement (3.37) values for the question that tests the extent to which the online 
consumer considers relevant that the product descriptions be classified by importance. Consequently, respondents who wish the products to be accompanied by a description based on importance also agree with the fact that ratings and reviews complement to formulating a pertinent product opinion and consider this information to being relevant and, thus, incorporated in the product description on the online sites.

Furthermore, in Table 9 it is shown the results of Pearson correlation analysis which highlights that between the two variables Ratings (Q6) and Reviews (Q7) there exists a positive correlation. As such, the online consumers which considers that Ratings are important features within the e-business practices, also ranks high the presence of reviews among the features of a product being sold online. Based on the significance value of the test we can state there is a significant positive relationship between Ratings and Reviews: $r(804)=0.200, p=0.000$.

Table 9. The Pearson correlation analysis between the variable Ratings (Q6) and Reviews (Q7). Source: own projection.

\begin{tabular}{lccc}
\hline & & Ratings (Q6) & Reviews (Q7) \\
\hline \multirow{3}{*}{ Ratings (Q6) } & Pearson Correlation & 1 & $0.200 * *$ \\
& Sig. (2-tailed) & & 0.000 \\
& N & 806 & 806 \\
\hline \multirow{2}{*}{ Reviews (Q7) } & Pearson Correlation & $0.200 * *$ & 1 \\
& Sig. (2-tailed) & 0.000 & 806 \\
& N & 806 &
\end{tabular}

\section{Discussion}

Based on the study we have pursued in the current research and by interpreting the obtained results we are able to affirm that people of Generation $Z$ are very much interested in shopping online and their majority possess the equipment (mobile devices connected to the Internet and payment methods) that allows them to act in the online market. There are some constraints/fears toward online shopping and the respondents named two: they said that they would like to buy online but often they do not trust online stores (1), or the lack of time to search for the right product makes them buy the products only in specialized stores (2). Though, for those who purchase online, the opinion toward including elements of the semantic web as features of product descriptions is what we have mainly investigated. We have noticed that the majority of the population that buy online agreed that it is important for a product that is being sold online to: (1) classify and display synonymous results and word families (39.7\% agreed), (2) display a relevance of text descriptions by classifying and displaying the search results by categories and subcategories (48.5\% agreed), (3) include explanations and hyperlink it to online dictionaries of terms (64.4\% agreed), and (4) classify the product descriptions by importance ( $56.7 \%$ agreed). As a result, including the semantic web elements in the products descriptions are features that the online website should implement in order to better serve their customers.

The items included in Table 2 proved that they enhanced the current study as being used as a base for the questionnaire. Furthermore, they justify that between consumers' online perception about product information and the semantic web there is a strong association.

The association between the perceived consumers' satisfaction and each enhancement was tested. The results shows a significant association between the degree in which the user appreciate the possibility to search for products within characteristics and consumers' online satisfaction. In addition, there was a significant association between the degree in which the consumer is interested in finding products with different names, but synonyms and consumer's perceived satisfaction.

An initial objective of the study was to identify if the enhancement on semantic web bases are in important factor for the perceived consumers' satisfaction. Preliminary work on e-services 
quality was undertaken by Liu et al. [17] which presents a model to evaluate online consumers' satisfaction. They have shown that the web site design, the information quality, the commercial issues, the transactional issues, the security, the payment, the delivery, and the services offered to online consumers influences directly and positively the online consumers' satisfaction. The current study found that there is a positive correlation between consumers' satisfaction and different enhancements related to semantic web.

As stated in the Introduction, semantic web technologies are considered [23] to be an approach to manage knowledge by using ontologies and semantic web standards. The most interesting finding was that the consumer considers knowledge graphs as being important in an e-commerce website. In addition, consumers consider that finding products within categories and subcategories of characteristics is an important feature, both for those who bought and for those who did not buy.

This finding has important implications for developing facet search results in e-commerce sites in a way not only necessary, but also with positive effects in terms of increasing the value of data manipulation.

The results of this study indicate that web commerce, web search, and semantic SEO with the Schema.org initiative supported by major search engines might be a consistent support for web publishers to embed structured data in their pages and benefit from improved presentation in search engine results pages.

An implication of this is the possibility that search engine optimization benefit from semantically describing content from the e-commerce sites on the bases of our study.

The more surprising result is associated with the possibility to have access to information related to characteristics in the order of their significance to the consumer. One of the issues that emerges from these findings is the enhanced analytics on the search results. Questions like what will be the next product that a client intends to buy, what will be the next promotion to take, and what will be the next good period to supply, might provide answers with enhanced content possibly based on natural language processing. A similar direction has been followed by the RMonto tool [50], an upper layer for the RapidMiner tool. It allows applying ontologies as background knowledge for several mining tasks, possibly combining relational and propositional subtasks. Another implementation of RDF data preprocessing for RapidMiner is by Khan [51]. Paulheim and Fürnkranz [52] suggested an automated method for data enrichment from linked data, pipelining entity recognition, feature generation, and feature selection.

Open issues that remain to be discussed are: aligning ontologies, discovering interlinked data, impact studies of using Schema.org, and/or other e-commerce ontologies with analytics.

This combination of findings provides some support for the conceptual premise that linked data technologies can provide more insight into data in the field of business that come from different sources.

Author Contributions: S.-C.N. conceived the questionnaire. The entire team contributed to writing the paper. V.-D.P. analyzed the data. O.D. documented the literature review. C.S. realized the Discussion section.

Funding: This research received no external funding.

Conflicts of Interest: The authors declare no conflict of interest.

\section{References}

1. Dewan, M.N.A.; Chowdhury, M.M.H.; Quaddus, M.A. Three Dimensional Components of e-Business Sustainability. In International Conference on E-Business and Telecommunications; Obaidat, M., Filipe, J., Eds.; Springer: Berlin/Heidelberg, Germany, 2014; Volume 455.

2. Pavaloaia, L. Environmental Information Reporting and Certification in Annual Reports. Procedia Econ. Financ. 2015, 20, 503-509. [CrossRef]

3. Radu, L.D. Green Cloud Computing: A Literature Survey. Symmetry 2017, 9, 295. [CrossRef] 
4. Lan, Y.; Hywel, R.T. E-business and Sustainable Development. Int. J. Environ. Sustain. Dev. 2006, 5, $262-274$. [CrossRef]

5. Lorenz, M.H.; Arnfalk, P.; Erdmann, L.; Goodman, J.; Lehmann, M.; Wäger, P.A. The relevance of information and communication technologies for environmental sustainability-A prospective simulation study. Environ. Model. Softw. 2006, 21, 1618-1629. [CrossRef]

6. Ekins, P. Economic Growth and Environmental Sustainability: The Prospects for Green Growth; Routledge: London, UK, 2000.

7. Jarvis, J. What would Google Do; HarperBusiness: New York, NY, USA, 2011; pp. 46-47. ISBN 0061709697.

8. Jacobson, P. A Great User Experience Boosts Revenu. 2016. Available online: http://blog.imonomy.com/agreat-user-experience-boosts-revenue/ (accessed on 30 April 2018).

9. Yue, K.; Wang, X.; Zhou, A. Underlying techniques for Web services: A survey. J. Softw. 2004, 15, 428-442.

10. Chen, M. Factors affecting the adoption and diffusion of XML and Web services standards for E-business systems. Int. J. Hum. Comput. Stud. 2003, 58, 259-279. [CrossRef]

11. Gottschalk, K.; Graham, S.; Kreger, H.; Snell, J. Introduction to web services architecture. IBM Syst. J. 2002, 41, 170-177. [CrossRef]

12. Tsalgatidou, A.; Pilioura, T. An overview of standards and related technology in web services. Distrib. Parallel Datab. 2002, 12, 135-162. [CrossRef]

13. Kim, D.J.; Song, Y.I.; Braynov, S.B.; Rao, H.R. A multidimensional trust formation model in B-to-C e-commerce: A conceptual framework and content analyses of academia/practitioner perspectives. Decis. Support Syst. 2005, 40, 143-165. [CrossRef]

14. Surcel, T.; Dinu, V. Auditul comerțului electronic în relație cu protecția consumatorilor. Rev. Amfiteatru Econ. 2007, 21, 115-120.

15. Egger, F.N. From Interactions to Transactions: Designing the Trust Experience for Business-to-Consumer Electronic Commerce; Eindhoven University of Technology: Eindhoven, The Netherlands, 2003; ISBN 90-386-1778-X. Available online: http:/ / www.webusability.ch/articles/egger2003trust.pdf (accessed on 30 April 2018).

16. Cheskin Research and Studio Archetype/Sapient. Ecommerce Trust Study; Technical Report; Cheskin Research and Studio Archetype/Sapient: Auburn, Alabama, USA, January 1999.

17. Liu, X.; He, M.; Gao, F.; Xie, P. An empirical study of online shopping customer satisfaction in China: A holistic perspective. Int. J. Retail Distrib. Manag. 2008, 36, 919-940. [CrossRef]

18. Santos, J. E-service quality: A model of virtual service quality dimensions. Manag. Serv. Q. 2003, 13, $233-246$. [CrossRef]

19. Janda, S.; Trocchia, P.J.; Gwinner, K.P. Customer perceptions of internet retail service quality. Int. J. Serv. Ind. Manag. 2002, 13, 412-431. [CrossRef]

20. Yang, Z.; Jun, M. Consumer perception of e-service quality: From internet purchaser and non-purchaser perspectives. J. Bus. Strateg. 2002, 19, 19-41.

21. Cheung, C.M.K.; Lee, M.K.O. Research Framework for Consumer Satisfaction with Internet Shopping. In Sprouts: Working Papers on Information Systems; City University of Hong Kong: Hong Kong, China, 2005; Volume 5, Available online: http:/ / sprouts.aisnet.org/5-26 (accessed on 30 April 2018).

22. Pleșea, D.; Pamfilie, R.; Maiorescu, I. Relația dintre structura comunicării și evitarea incertitudinii reflectată în desgnul site-urilor web românești. Rev. Amfiteatru Econ. 2011, 8, 628-635.

23. Singh, R.; Iyer, L.S.; Salam, A.F. Semantic eBusiness. Int. J. Semant. Web Inf. Syst. 2005, 1, 19-35. [CrossRef]

24. Janev, V.; Vrane, S. Applicability assessment of Semantic Web technologies. Inf. Process. Manag. 2010, 47, 507-517. [CrossRef]

25. Gruber, T. The Role of Common Ontology in Achieving Sharable, Reusable Knowledge Bases. In Principles of Knowledge Representation and Reasoning; Allen, J., Fikes, R., Sandewall, E., Eds.; Morgan Kaufman: San Mateo, CA, USA, 1991; pp. 601-602.

26. Kashyap, V.; Sheth, A. Semantics-based Information Brokering. In Proceedings of the Third International Conference on Information and Knowledge Management (CIKM), Gaithersburg, MD, USA, 29 November-2 December 1994; pp. 363-370. 
27. Sheth, A.P. Changing Focus on Interoperability in Information Systems: From System, Syntax, Structure to Semantics. In Interoperating Geographic Information Systems; Goodchild, M., Egenhofer, M., Fegeas, R., Kottman, C., Eds.; Interoperating Geographic Information Systems; The Springer International Series in Engineering and Computer Science; Springer: Boston, MA, USA, 1998; Volume 495.

28. Abramowicz, W.; Auer, S.; Heath, T. Linked Data in Business. Bus. Inf. Syst. Eng. 2016, 58. [CrossRef]

29. Search Engine Watch. The State of Schema.org. Available online: https://searchenginewatch.com/2017/04/ 18/the-state-of-schema-org-what-are-the-biggest-challenges-surrounding-schema-markup/ (accessed on 30 April 2018).

30. Ubitech. Linked Data Analytics. 2018. Available online: https://www.ubitech.eu/technology/linked-dataanalytics/ (accessed on 30 April 2018).

31. Delone, W.H.; McLean, E.R. The DeLone and McLean model of information systems success: A ten-year update. J. Manag. Inf. Syst. 2003, 19, 9-30. [CrossRef]

32. Koivunen, M.R.; Miller, E. W3C Semantic Web Activity. In Semantic Web Kick-off Seminar in Finland; World Wide Web Consortium (W3C): Helsinki, Finland, 7 November 2011; Retrieved 26 November 2011.

33. Information Resources. Information Retrieval and Management: Concepts, Methodologies, Tools, and Applications; IGI Global: Hershey, PA, USA, 2018; ISBN 978-1522551911.

34. Hepp, M. The Web of Data for E-Commerce: Schema.org and GoodRelations for Researchers and Practitioners. In International Conference on Web Engineering; Cimiano, P., Frasincar, F., Houben, G.J., Schwabe, D., Eds.; Lecture Notes in Computer Science; Springer: Cham, Switzerland, 2015; Volume 9114. [CrossRef]

35. Evanschitzky, H.; Gopalkrishnan, R.I.; Josef, H.; Dieter, A. E-satisfaction: A re-examination. J. Retail. 2004, 80, 239-247. [CrossRef]

36. Szymanski, D.M.; Hise, R.T. E-satisfaction: An initial examination. J. Retail. 2000, 76, 309-322. [CrossRef]

37. Kim, S.Y.; Lim, Y.J. Consumers' perceived importance of and satisfaction with internet shopping. Electron. Mark. 2001, 11, 148-154. [CrossRef]

38. Singhal, A. Modern information retrieval: A brief overview. IEEE Data Eng. Bull. 2001, 24, 35-43.

39. Stolz, A.; Hepp, M. Adaptive faceted search for product comparison on the web of data. In International Conference on Web Engineering; Springer: Cham, Switzerland, 2015; pp. 420-429.

40. Paulheim, H. Knowledge graph refinement: A survey of approaches and evaluation methods. Seman. Web 2017, 8, 489-508. [CrossRef]

41. Garcia-Crespo, A.; Ruiz-Mezcua, B.; Lopez-Cuadrado, J.L.; Gonzalez-Carrasco, I. Semantic model for knowledge representation in e-business. Knowl.-Based. Syst. 2011, 24, 282-296. [CrossRef]

42. Guha, R.V.; Brickley, D.; Macbeth, S. Schema. org: Evolution of structured data on the web. Commun. ACM 2016, 59, 44-51. [CrossRef]

43. Krutil, J.; Kudelka, M.; Snasel, V. Web page classification based on Schema. org collection. In Computational Aspects of Social Networks (CASoN); IEEE: Piscataway, NJ, USA, 2012; pp. 356-360. [CrossRef]

44. Meymandpour, R.; Davis, J.G. Recommendations using linked data. In Proceedings of the 5th Ph.D. Workshop on Information and Knowledge, Maui, HI, USA, 2 November 2012; pp. 75-82. [CrossRef]

45. Huang, Z.; Benyoucef, M. From e-commerce to social commerce: A close look at design features. Electron. Commer. Res. Appl. 2013, 12, 246-259. [CrossRef]

46. Muhleisen, H.; Bizer, C. Web Data Commons-Extracting Structured Data from Two Large Web Corpora. LDOW 2012, 937, 133-145.

47. Bizer, C.; Eckert, K.; Meusel, R.; Mühleisen, H.; Schuhmacher, M.; Völker, J. Deployment of rdfa, microdata, and microformats on the web-A quantitative analysis. In International Semantic Web Conference; Springer: Berlin/Heidelberg, Germany, 2013; pp. 17-32.

48. Anastasiei, B.; Dospinescu, N. A model of the relationships between the Big Five personality traits and the motivations to deliver word-of-mouth online. PSIHOLOGIJA 2018, 1-12. [CrossRef]

49. Heath, T.; Motta, E. Revyu.com: A Reviewing and Rating Site for the Web of Data. In The Semantic Web; Springer: Berlin/Heidelberg, Germany, 2007; pp. 895-902.

50. Potoniec, J.; Ławrynowicz, A. Rmonto: Ontological extension to Rapid-Miner. In Proceedings of the Poster and Demo Session of the ISWC 2011, 10th International Semantic Web Conference, Bonn, Germany, 23-27 October 2011. 
51. Khan, M.A.; Grimnes, G.A.; Dengel, A. Two pre-processing operators for improved learning from Semantic Web data. First RapidMiner Community Meeting and Conference (RCOMM 2010). Available online: https:/ / www.researchgate.net/profile/Andreas_Dengel/publication/268348050_Two_pre-processing_ operators_for_improved_learning_from_Semantic_Web_data/links/54d0b61d0cf298d65668296e/Twopre-processing-operators-for-improved-learning-from-Semantic-Web-data.pdf (accessed on 30 April 2018).

52. Paulheim, H.; Fürnkranz, J. Unsupervised Generation of Data Mining Features from Linked Open Data. In Proceedings of the 2nd International Conference on Web Intelligence, Mining and Semantics, Craiova, Romania, 13-15 June 2012; ACM: New York, NY, USA, 2012. [CrossRef]

(c) (C) 2018 by the authors. Licensee MDPI, Basel, Switzerland. This article is an open access article distributed under the terms and conditions of the Creative Commons Attribution (CC BY) license (http://creativecommons.org/licenses/by/4.0/). 